\title{
Soft law, migration and climate change governance
}

\author{
Elizabeth Ferris \\ Research Professor, Georgetown University, Washington, DC, USA
}

\section{Jonas Bergmann*}

Consultant, World Bank, Climate Change Policy Team and Global Knowledge Partnership on Migration and Development (KNOMAD), Washington, DC, USA

This article explores alternative ways that legal and normative frameworks can be used to uphold the rights of those who are displaced internally or across borders in the context of anthropogenic climate change. In particular, we argue that more efforts should be focused on developing soft law rather than trying to fit those displaced because of the effects of climate change into existing legal frameworks. The present hard law system governing the movement of people is not equipped to handle the complexities of population movements resulting from the effects of climate change, and an adequate transformation of these often static legal regimes is improbable. By contrast, soft law offers a number of advantages particularly well suited to the characteristics of those who move because of the effects of climate change and who currently fall into the gaps between protection frameworks. On the downside, soft law norms are not binding and the multiplicity of such initiatives may contribute to a fragmentation of protection systems, resources and attention. Therefore, the present article concludes by arguing for a two-track approach in which both soft and hard law contributes to the protection of those displaced in the context of climate change. On the one hand, in order to address some of the current protection gaps, existing, emergent and new soft law needs to be used and implemented more thoroughly. At the same time, ways forward also include encouraging the more effective and dynamic implementation of hard law, especially through regionalization, complementary protection and the deployment of some features of emerging climate change regimes.

Keywords: climate change, environment, migration, displacement, human rights, protection, soft law

\section{INTRODUCTION: PROTECTING PEOPLE DISPLACED IN THE CONTEXT OF CLIMATE CHANGE}

This article explores alternative ways that legal and normative frameworks can be used to uphold the rights of those who are displaced internally or across borders in the context of anthropogenic climate change. ${ }^{1}$ In particular, we argue that more efforts should be focused on developing soft law rather than trying to fit those displaced because of the effects of climate change into existing legal frameworks. The present

* The authors wish to thank the peer reviewers for their valuable input.

1. This paper recognizes that displacement is only one aspect of mobility influenced by the effects of climate change, recognizing that it is likely that many people will move in anticipation of the effects of climate change through existing migration pathways. For climate-change-induced 
hard law system governing the movement of people is not equipped to handle the complexities of population movements in the context of climate change, and it is improbable that these often static legal regimes can be adequately transformed. In contrast, we argue that soft law offers a number of advantages particularly well suited to the characteristics of those who move because of the effects of climate change, especially if complemented by some of the more potent aspects of hard law.

This article begins by considering the assumptions on which we base our arguments. It then turns to analysis of the relative advantages and limitations of soft law and examines a number of initiatives which are already breaking new conceptual ground. Finally, the article examines possibilities to complement these soft law initiatives through hard law in a 'multi-track approach' to protect those displaced because of the effects of climate change. ${ }^{2}$ Before turning to these arguments, we briefly explain the particularly vexing problem of terminology.

There is agreement over the fact that people will move because of the effects of climate change (and there is a growing body of evidence that people are, in fact, moving now). ${ }^{3}$ There is, however, no agreement on which terms and legal categorizations are adequate for this group of people. ${ }^{4}$ The term 'climate refugees' is still widely used by the media and advocacy organizations, yet does not apply, as discussed below. Others have suggested 'environmental migrants' or 'climate-displaced persons', but both of these are problematic because of the way in which climate - and environmental factors generally - interact with other factors in individual decisions to move. As Mayer argues, making the case that climate change causes human displacement requires evidence of two causal relationships: first, a link between climate change and a particular environmental phenomenon, and second, between the environmental phenomenon and the decision of an individual to move. ${ }^{5}$ To call all those who are displaced or who move in anticipation of sudden-onset disasters 'climate displaced' is misleading, even though protection challenges may be similar to those in the case of displacements resulting from a range of other causes. And the situation is even more complex in the case of slow-onset consequences of climate change where environmental factors interact with economic, social, family, cultural and other factors (including opportunities and risks of moving) leading to decisions to move.

The system of international law governing the cross-border movement of people is largely based on the reasons for such movements. When people move because they are forced to do so due to persecution or conflict, they may be considered to be

mobility writ large, it should be noted that international migration law provides a framework, including both treaty obligations under international human rights law and soft law initiatives encompassing dozens of regional processes and agreements.

2. V Kolmannskog and L Trebbi, 'Climate Change, Natural Disasters and Displacement: A Multi-track Approach to Filling the Protection Gaps' (2010) 92(879) International Review of the Red Cross 713 .

3. Foresight, 'Migration and Global Environmental Change: Future Challenges and Opportunities' (2011) <https://www.gov.uk/government/uploads/system/uploads/attachment_data/ file/287717/11-1116-migration-and-global-environmental-change.pdf $>$ accessed 30 May 2016; IPCC, 'Fifth Assessment Report' (2013-2014) <https://www.ipcc.ch/report/ar5/> accessed 26 May 2016.

4. OV Dun and F Gemenne, 'Defining "Environmental Migration"” [2008] Forced Migration Review 10.

5. B Mayer, Concept of Climate Migration Advocacy and its Prospects (Edward Elgar Publishing, Cheltenham 2016). 
refugees and protected by international refugee law, as well as by various regional and other instruments. ${ }^{6}$ Climate-related displacement, however, is not covered by the definitions of the current refugee protection instruments. ${ }^{7}$ The Geneva definition has both a geographic and a causal component - it only applies to cross-border movement and to those with a well-founded fear of persecution on the basis of race, religion, nationality, membership of a particular social group or political opinion, and who no longer enjoy the protection of their governments. In the context of climate change, refugee law may thus only be applicable in very limited instances when disasters create conflict, persecution, or a breakdown of public order. While some authors have argued that the definition of 'refugee' should be extended to include new types of 'survival migration', ${ }^{8}$ such as climate or environmental 'refugees', ${ }^{9}$ most experts in international law reject this avenue due to the conceptual, legal and practical challenges of enforcing such extensions. ${ }^{10}$ Expanding the scope of the present refugee definition to encompass a large new group of beneficiaries seems neither feasible nor desirable; ${ }^{11}$ such expansion could potentially further limit admission and reception policies for those qualifying under the current regime and lead to even more restrictive interpretations in the future, a concern also expressed by the UNHCR Executive Committee. ${ }^{12}$ That said, hard law does offer some opportunities to improve protection prospects as

6. The Organization of African Unity adopted the legally binding Convention Governing the Specific Aspects of Refugee Problems in Africa in 1969; Latin American governments adopted the unbinding Cartagena Declaration in 1984, which is applied by most of them in practice (UNHCR, Refugee Protection: A Guide to International Refugee Law (Handbook for parliamentarians no. 2, 2001, Inter-Parliamentary Union; Office of the United Nations High Commissioner for Refugees 2001)); and several regional human rights regimes include rights related to asylum. Non-Refoulement is prohibited explicitly or through interpretation by the Convention against Torture (Article 3) and various other instruments, and has become part of customary international law (ibid).

7. Nansen Initiative, 'Protection Agenda' (2015) <https://nanseninitiative.org/wp-content/ uploads/2015/02/protection-agenda-volume-1.pdf> and <https://nanseninitiative.org/wp-content/ uploads/2015/02/protection-agenda-volume-2.pdf> accessed 25 May 2016.

8. A Betts, Survival Migration: Failed Governance and the Crisis of Displacement (Cornell University Press, Ithaca 2013).

9. R Baird and C Aid, Human Tide: The Real Migration Crisis. A Christian Aid Report (Christian Aid 2007); F Biermann and Ingrid Boas, 'Protecting Climate Refugees: The Case for a Global Protocol' (2008) 50(6) Environment: Science and Policy for Sustainable Development 8; VO Kolmannskog, Future Floods of Refugees: A Comment on Climate Change, Conflict and Forced Migration (Norwegian Refugee Council 2008).

10. J McAdam, 'Review Essay: From Economic Refugees to Climate Refugees' (2009) 10 Melb J Int'l L 579; J McAdam, Climate Change, Forced Migration, and International Law (Oxford University Press, Oxford 2012); R Zetter, 'Climate Change and Displacement Legal and Normative Frameworks' [2008] Forced Migration Review 62; R Zetter, 'Protecting People Displaced by Climate Change: Some Conceptual Challenges' in J McAdam (ed), Climate Change and Displacement: Multidisciplinary Perspectives (Hart, Oxford 2010).

11. Stretching the refugee definition is problematic since climate threats do not fall into any of the five convention grounds. They are neither persecutory in nature nor executed by governments of the countries of origin. Most climate-change-related mobility is predicted to be internal, thus failing to satisfy the cross-border criterion of the Geneva Convention. Finally, the Refugee Convention is already highly contested and has historically faced considerable constraints, especially in times of rising case numbers.

12. B Glahn, “'Climate Refugees”? Addressing the International Legal Gaps' (11 June 2009) <http://www.ibanet.org/Article/Detail.aspx?ArticleUid=B51C02C1-3C27-4AE3-B4C47E350EB0F442> accessed 27 May 2016. 
one component of a multi-track approach, and we return to this possibility in section 4 of this article.

When people move voluntarily, for example in search of employment or to be near family members or to find better opportunities, they are considered to be migrants and thus to fall under international human rights law and migration law. ${ }^{13}$ However, the international system for governance of migration provides little definitional clarity and the rules on the admission of migrants are largely the responsibility of national authorities. Many of those who move because of the effects of climate change, particularly those who move in anticipation of such changes, will be considered to be migrants. Under current international law, such migrants are not entitled to special treatment. ${ }^{14}$ And yet it is likely that their movement is not a completely voluntary one - the line between displacement and migration is often a blurred one.

Facing this complexity and the sensitivity of the topic, it is unsurprising that no terminological consensus on the issue has yet emerged. We are left with the bulky and inelegant phrase 'those displaced in the context of climate change', which does not make a judgement about whether the effects of climate change are the single driving reason for movement or interact with other factors to lead individuals to decide to move. That said, this and other similarly 'clinical terms' certainly have their own normative implications; they may, as Gemenne argues, depoliticize the issue and fail to recognize how climate change is indeed imposed by a few states on some of the most at-risk groups. ${ }^{15}$

\section{ASSUMPTIONS}

Before examining the reasons why soft law is particularly well suited to respond to the nuances and complexity of displacement in the context of climate change, we consider four assumptions on which our arguments are based.

The first assumption is that the effects of climate change are already leading people to leave their communities and will cause more movement in the future, either as voluntary (anticipatory) migration, as involuntary migration or displacement, or as the result of relocations undertaken to protect people from the effects of climate change. ${ }^{16}$ Such movement may be caused, amongst other things, by more frequent and intense climate-related

13. B Opeskin, R Perruchoud and J Redpath-Cross (eds), Foundations of International Migration Law (Cambridge University Press, Cambridge 2012) ch. 1.

14. K Warner, Environmental Change and Migration: Issues for European Governance and Migration Management, $2012<\mathrm{http} / / /$ migrationeducation.de/56.1.html?\&rid=208\&cHash= 6cf222c08c5309a7e2288d393f5ba88d>.

15. F Gemenne, 'One Good Reason to Speak of "Climate Refugees"' [2015] Forced Migration Review 70; H Ransan-Cooper and others, 'Being(s) Framed: The Means and Ends of Framing Environmental Migrants' (2015) 35 Global Environmental Change 106.

16. R Black et al., 'The Effect of Environmental Change on Human Migration' (2011) 21 Global Environmental Change S3-S11; IPCC (n 3). While our article does not discuss this issue in detail, entrapped or immobile populations may face the greatest protection challenges. S Caney, 'Climate Change, Human Rights, and Moral Thresholds' [2010] Climate Ethics: Essential Readings 163. In a few instances a warming climate may also create new economic opportunities that attract people, as is occurring in Greenland, cf E Rosenthal, 'A Melting Greenland Weighs Perils Against Potential' The New York Times (23 September 2012) $<$ http://www.nytimes.com/2012/09/24/science/earth/melting-greenland-weighs-perils-againstpotential.html> accessed 30 May 2016. 
hazards, slow-onset disasters such as droughts, an increasing risk of conflict, and displacement induced by actions to mitigate the effects of climate change. The fifth assessment report by the IPCC, for instance, confirms with high confidence that displacement due to extreme events will be more likely to increase and become more permanent. ${ }^{17}$ For both internal and international movement, climate change is likely to function as a threat multiplier rather than being the only reason that people move, creating a particular challenge for normative frameworks based on the causes of movement. ${ }^{18}$

The second assumption is that climate-change-related displacement will lead in many instances to increased risks of human rights violations, as has been acknowledged by the UN Human Rights Council. ${ }^{19}$ Displacement may also occur multiple times, depleting resources needed to mitigate increasing risks.

Thirdly, the development both of normative frameworks and systems of governance to respond to rising numbers of people displaced in the context of climate change will be particularly challenging. For internal displacement - likely to be the most important in the context of climate change $e^{20}$ - states have traditionally been unwilling to accept instruments perceived to be encroaching on states' sovereign responsibility for their internal affairs. ${ }^{21}$ The governance of cross-border displacement of those who fall outside the realm of international refugee law is equally politicized and controversial. ${ }^{22}$ Questions of historical responsibility, liability and compensation make it unlikely that any binding legal requirement implying a responsibility to allow entry to those who are displaced because of the effects of climate change can be developed.

Fourthly, we assume that legal and normative frameworks, that is, 'binding international law as well as non-legally binding best practices and principles' ${ }^{23}$ can play an important role in protecting people displaced in the context of climate change, even though the existence of a normative framework is never enough. A normative framework - whether a binding international treaty or a soft law instrument - must be translated into policy and implemented in order to have an effect on the protection of human beings. Nonetheless, such frameworks can induce compliance, either through persuasion or coercion. ${ }^{24}$ In some cases, they are implemented or partially implemented in ways that improve the human rights of affected persons. In other cases, they can serve an aspirational purpose. They are also important tools for human rights and other civil society groups to hold governments accountable.

\section{IPCC (n 3) 1.}

18. B Mayer, 'Environmental Migration: Prospects for a Regional Governance in the AsiaPacific Region' (2013) 16 Asia Pacific Journal of Environmental Law 77. See also E Ferris, 'Climate Change, Migration and the Incredibly Complicated Task of Influencing Policy' (New York 2015) <http://cmsny.org/climate-change-migration-policy/> accessed 6 June 2016; Foresight (n 3) 13 f; US Department of Defense, 'Climate Change Adaptation Roadmap' (2014) <http://iconnectdots.com/files/CCARprint_wForeword_c.pdf> accessed 30 May 2016. 19. Cf, amongst others, UNGA Resolutions A/HRC res. 7/23, A/HRC res. 10/4, and A/HRC/ $10 / 61$.

20. Foresight (n 3).

21. Mayer, 'Environmental Migration: Prospects for a Regional Governance in the AsiaPacific Region' (n 18).

22. Nansen Initiative (n 7).

23. SF Martin, 'The Legal and Normative Framework of International Migration' (September 2005), $1<$ http://iom.ch/jahia/webdav/site/myjahiasite/shared/shared/mainsite/policy_and_ research/gcim/tp/TP9.pdf> accessed 24 June 2016.

24. EM Hafner-Burton, Making Human Rights a Reality (Princeton University Press, Princeton, NJ 2013). 
The importance of protection regimes is beyond doubt, and a wide range of work has analysed those relevant for displacement in the context of climate change. ${ }^{25}$ Yet research has mostly scrutinized the potential of hard law, and insufficient focus has been placed upon the dynamic field of soft law, particularly some of the more recent important soft law developments. This gap persists despite the fact that some scholars ${ }^{26}$ do acknowledge the potential of soft law as a 'springboard' for better frameworks, ${ }^{27}$ and that others have argued in favour of a new, unifying soft law framework for the 'protection of vulnerable irregular migrants', ${ }^{28}$ including climate change-related ones. ${ }^{29}$ However, most of the work in this field only addresses the issue en passant. ${ }^{30}$ The small number of more ambitious analyses of soft law such as the one by McAdam ${ }^{31}$ were written several years ago and do not reflect the latest important developments in the field; updates by the same author have focused mostly on the Nansen Initiative as one example of soft law. ${ }^{32}$

These gaps in the existing scholarly literature, recent institutional developments and the recognition that soft law can provide a certain protection potential for climate-related displacement, call for a more nuanced and up-to-date analysis. Accordingly, the next

25. Eg R Zetter, 'Protecting Environmentally Displaced People: Developing the Capacity of Legal and Normative Frameworks' [2011] Refugee Studies Centre: Oxford University; R Zetter, 'Protecting People Displaced by Climate Change: Some Conceptual Challenges' in J McAdam (ed), Climate Change and Displacement: Multidisciplinary Perspectives (Hart, Oxford 2010); $\mathrm{J}$ McAdam, Climate Change, Forced Migration, and International Law (Oxford University Press, Oxford 2012); K Koser, 'Climate Change and Internal Displacement: Challenges to the Normative Framework' in E Piguet, A Pécoud and P de Guchteneire (eds), Migration and Climate Change (UNESCO/Cambridge University Press, Cambridge 2011); J Mcadam, 'Climate Change-Related Displacement of Persons' in CP Carlarne, KR Gray and R Tarasofsky (eds), The Oxford Handbook of International Climate Change Law (Oxford University Press, Oxford 2016).

26. Eg A Betts, "Towards a "Soft Law" Framework for the Protection of Vulnerable Irregular Migrants' (2010) 22(2) International Journal of Refugee Law 209; Koser (ibid); J McAdam, 'Refusing "Refuge" in the Pacific: (De)constructing Climate-Induced Displacement in International Law' in E Piguet and A Pecoud (eds), Migration and Climate Change (Cambridge University Press, Cambridge 2011) 25.

27. McAdam, "Refusing "Refuge" in the Pacific: (De)constructing Climate-Induced Displacement in International Law' (ibid) 25.

28. Betts (n 26).

29. In a similar vein as Betts, cf McAdam, "Refusing "Refuge" in the Pacific: (De)constructing Climate-Induced Displacement in International Law' (n 26); Vikram Kolmannskog, 'Climate Change, Environmental Displacement, and International Law' (2012) 24(8) Journal of International Development 1071; Jane McAdam, 'Creating New Norms on Climate Change, Natural Disasters and Displacement: International Developments 2010-2013' (2014) 29(2) Refuge: Canada's Journal on Refugees.

30. Some pieces mentioning soft law in such a cursory way are, eg: K Warner, 'Global Environmental Change and Migration: Governance Challenges' (2010) 20(3) Global Environmental Change 402; B Mayer, 'International Legal Challenges of Climate-Induced Migration: Proposal for an International Legal Framework' (2011) 22 Colo J Int'l Envtl L \& Pol'y 357; B Mayer, 'Climate Change, Migration, and International Law in Southeast Asia' [2015] Adaptation to Climate Change: ASEAN and Comparative Experiences 337.

31. McAdam, Climate Change, Forced Migration, and International Law (n 10).

32. J McAdam, 'Climate Change-Related Displacement of Persons' in CP Carlarne, KR Gray and R Tarasofsky (eds), The Oxford Handbook of International Climate Change Law (Oxford University Press, Oxford 2016); McAdam, 'Creating New Norms on Climate Change, Natural Disasters and Displacement: International Developments 2010-2013' (n 29). 
section of this paper explores how soft law mechanisms can contribute to the protection of those displaced in the context of climate change more thoroughly. The following section turns to ways in which efforts to adapt hard law may complement these processes to develop normative guidance for the protection of those who move because of the effects of climate change.

\section{PROTECTION POTENTIAL OF SOFT LAW}

Soft law encompasses a range of non-treaty agreements, including UN declarations, decisions of the UN Human Rights Committee, conclusions of UNHCR's Executive Committee, rulings of the International Court of Justice, and guidance developed by experts. ${ }^{33}$ Soft law has proliferated in recent decades, both as a result of the growth in the number of actors, and due to the increasing number of issues where agreements are needed to meet specific needs.

The concept of 'soft law', although commonly used, is a contradiction in terms. Soft law is not legally binding and is created via different processes than hard law, which according to the International Court of Justice encompasses treaty law, international customs and general, internationally recognized principles of law. ${ }^{34}$ That said, soft law can set the stage for the development of international customary law, ${ }^{35}$ as a reflection of a subjective obligation assumed by states, if their settled practice aligns with this opinio iuris. ${ }^{36}$

The advantages of soft law are many. Non-binding agreements are generally easier to negotiate because they are less binding on states, and thus perceived to be less threatening to state sovereignty. As Hillgenberg explains, these agreements are negotiated because states do not want a full-fledged law, non-compliance with which would amount to a breach of international law. ${ }^{37}$ Soft law processes can yield relatively rapid results as they bypass lengthy and politically contentious domestic ratification. In addition, soft law documents can be drafted by non-state actors (eg legal experts) and can involve stakeholders not legally qualified to negotiate binding international law. Furthermore, soft law is more easily changed and hence more flexible in responding to dynamic situations. It also avoids overburdening the international system with hard law. ${ }^{38}$

The principal disadvantage of soft law agreements is that they are not legally binding, and non-compliance does not produce any legal consequences. By contrast, the laws of state responsibility determine liability and remedies for a breach of international hard law obligations. ${ }^{39}$ Furthermore, while treaties generally have some sort of monitoring,

33. H Hillgenberg, 'A Fresh Look at Soft Law' (1999) 10(3) European Journal of International Law 499, 501.

34. ICJ, 'Statute of the International Court of Justice' (18 April 1946), Art 38 I.

35. Ibid Art 38 I(b), defining 'international customs, as evidence of a general practice accepted as law'.

36. ICJ, 'Case Concerning Military and Paramilitary Activities in and against Nicaragua (Nicaragua v. United States of America), Merits: I.C.J. Reports 1986, p. 14; General List No. 70' (27 June 1986).

37. Hillgenberg (n 33) 504.

38. Ibid 501.

39. ILC, 'Draft Articles on the Responsibility of States for Internationally Wrongful Acts, Report of the ILC on the Work of its Fifty-third Session, UN GAOR, 56th Sess, Supp No 10, p 43, UN Doc A/56/10' (2001) <http://www.un.org/ga/search/view_doc.asp?symbol=A/ 56/10\%28SUPP\%29> accessed 6 June 2016. 
reporting or compliance mechanism, these are less common in soft law. Nonetheless, some non-treaty agreements can be enforced in a soft manner by the establishment of control mechanisms that parties enter into, ${ }^{40}$ for example the follow-up conferences of the Commission on Security and Cooperation in Europe (CSCE). That said, there are different levels of obligations - and ambition - in soft law and states often find it advantageous to comply with international soft law. For example, all 193 UN Member States have participated in the Universal Periodic Review of Human Rights, even though there are no legally enforceable penalties for failure to do so.

Soft law plays an increasingly important role in the international system. ${ }^{41}$ In a three-year study, Shelton found that soft law is used to supplement or to fill gaps in binding international law, rather than as a substitute for binding law. ${ }^{42}$ In the human rights sector, soft law was also used primarily as a precursor for the development of new hard law. In the area of environmental law, soft law has often been used subsequent to treaties in order to clarify principles in the treaty text. Shelton stresses the importance of leadership for the development and especially for the implementation of soft law and found that regional agreements are often more important than global ones. ${ }^{43}$

International migration law ${ }^{44}$ is characterized by a few legally binding treaties and a much larger number of bilateral, regional and international manifestations of soft law, which together provide important guidance for managing particular aspects of international migration. ${ }^{45}$ There are also state-led processes creating new migration-related soft

40. Hillgenberg (n 33) 511.

41. For further discussions of soft law, see KW Abbott and D Snidal, 'Hard and Soft Law in International Governance' (2000) 54(03) International Organization 421; G Shaffer and MA Pollack, 'Hard vs. Soft Law: Alternatives, Complements and Antagonists in International Governance' (2010) 94 Minnesota Law Review 706.

42. D Shelton, Commitment and Compliance: The Role of Non-binding Norms in the International Legal System (Oxford University Press on Demand 2003).

43. Ibid.

44. While international legal instruments relevant to migrants and migration are drawn from several bodies of international law and are not consolidated in a single instrument, the IOM collectively refers to this body of law as 'international migration law' and works with governments around the world at their request to help them develop and implement national legislation consistent with these international standards, and trains government officials on their effective use. See RI Cholewinski, R Perruchoud and E MacDonald, International Migration Law: Developing Paradigms and Key Challenges (T.M.C. Asser Press, The Hague 2007); R Perruchoud and K Tömölová, Compendium of International Migration Law Instruments (T.M.C. Asser Press, The Hague 2007). In addition, the International Migrants Bill of Rights has been developed in recent years by Georgetown University and collaborating institutions to consolidate in a single document the core rights of all migrants, and can be a useful guide. See 'International Migrants Bill of Rights' 28 Georgetown Immigr LJ 23.

45. ILO, 'Fair Migration: Setting an ILO Agenda: Report of the ILO Director General' (9 May 2014) <http://ilo.org/wcmsp5/groups/public/—ed_norm/—relconf/documents/meetingdocument/ wcms_242879.pdf> accessed 30 May 2016; IOM, 'Regional Inter-State Consultation Mechanisms on Migration: Approaches, Recent Activities and Implications for Global Governance of Migration' (10 May 2013), IOM Migration Research Series No. $45<\mathrm{http}: / /$ publications.iom. int/system/files/pdf/mrs45_en_10may2013.pdf> accessed 30 May 2016; IOM, 'Migration Governance Framework: C/106/40' (4 November 2015) <https://governingbodies.iom.int/system/ files/en/council/106/C-106-40-Migration-Governance-Framework.pdf> accessed 30 May 2016; IOM, 'About the International Recruitment Integrity System' (October 2015) <http://iris.iom. int/sites/default/files/document/IRIS_BROCHURE_201510_final_PDF_Distribution.pdf> 
law. The Migrants in Countries in Crisis Initiative (MICIC) ${ }^{46}$ for instance, provides guidance for responding to migrants caught up in crises - either disasters or conflicts. The examples discussed below were chosen to present a variety of instruments developed at different points in time to provide guidance on specific groups of concern. They include both general principles and operational guidelines. Some were developed in the context of the United Nations or through a state-led process, while others were developed by legal experts. These examples provide a cross-section of some of the most well-known soft law initiatives relevant to the protection of the rights of those displaced because of the effects of climate change - acknowledging that there are, of course, many other examples of relevant soft law. ${ }^{47}$

\subsection{Guiding Principles on Internal Displacement}

The Guiding Principles on Internal Displacement, developed in 1998 and affirmed by the World Summit of 2005, explicitly apply to those displaced by disasters as well as by conflict. ${ }^{48}$ The Principles were developed to identify gaps in existing international law and to provide appropriate guidance. A series of consultations of legal experts, meeting under the guidance of the Representative of the Secretary-General on Internally Displaced Persons (IDPs), compiled a list of 30 principles from existing hard law particularly applicable to IDPs. The development of the Guiding Principles was based not only on the expertise of well-regarded international lawyers, but included a broad-based consultative process with support from key governments and international agencies. ${ }^{49}$

While not a legally binding document, the Guiding Principles are based on and draw out the relevant norms of international human rights and humanitarian law (and by analogy, refugee law) and apply them to situations of internal displacement. The Guiding Principles affirm that states bear the primary responsibility for the protection of people - both citizens and habitual residents - within their area of jurisdiction (Principle 3). They recognize that individuals have a right to protection from arbitrary displacement as well as to assistance and protection when they are displaced (Principles 3 and 6). Moreover, the Principles also enshrine the right to find durable solutions to displacement - return or settlement in the place of displacement or in another part of the country (Principle 28).

accessed 30 May 2016; OHCHR, 'Recommended Principles and Guidelines on Human Rights at International Borders' (2014) <http://www.ohchr.org/Documents/Issues/Migration/OHCHR_ Recommended_Principles_Guidelines.pdf $>$ accessed 31 May 2016; ILO, Multilateral Framework on Labour Migration: Non-binding Principles and Guidelines for a Rights-based Approach to Labour Migration (ILO 2006).

46. MICIC, 'Overview of the MICIC Initiative' (April 2016) <https://micicinitiative.iom.int/ sites/default/files/document/MICIC\%20Overview\%20REVISED.13\%20April16.pdf> accessed 25 May 2016.

47. See, for example, the Peninsula Principles, developed in 2013, to provide guidance for climate displacement: Displacement Solutions, 'The Peninsula Principles on Climate Displacement Within States' (18 August 2013) <http://displacementsolutions.org/wp-content/uploads/ 2014/12/Peninsula-Principles.pdf> accessed 24 June 2016.

48. UN OCHA, 'Guiding Principles on Internal Displacement: E/CN.4/1998/53/Add.2' (1998) <http://www.brookings.edu/ /media/Projects/idp/GPEnglish.pdf > accessed 30 May 2016.

49. R Cohen, 'Lessons Learned from the Development of the Guiding Principles on Internal Displacement' [2013] ISIM, The Crisis Migration Project 1. 
The Guiding Principles are often considered to be one of the most effective soft law mechanisms. Now available in 60 languages, they have been used by many governments as the basis for the development of national laws and policies on IDPs, and have been incorporated into policies and guidelines for humanitarian actors. Perhaps most important to the success of the Guiding Principles was the fact that they were all drawn from existing international law, deflecting criticism that they were not the product of an inter-governmental negotiating process. ${ }^{50}$ The Guiding Principles also proved to be useful to governments grappling with largescale internal displacement in providing concrete guidance as to their responsibilities. The Representative of the Secretary-General, a highly regarded independent expert operating under the authority of both the Secretary-General and the UN's human rights mechanism, provided oversight to the process, thus offering more legitimacy than an independent academic expert could have done. And yet the fact that the Representative was not a UN employee gave him a flexibility to work with a wide range of stakeholders and to oversee a broad dissemination process which was at least as important as the actual compilation of the Principles.

The Guiding Principles have been successful in providing a normative framework that has undoubtedly protected the rights of some IDPs in at least some situations. The fact that the Principles have been translated into national laws and policies by more than 20 governments is perhaps the most important expression of their utility. However, no country has fully implemented the Guiding Principles. ${ }^{51}$ Even when they are incorporated into national laws and policies, the almost exclusive focus has been on those displaced by conflict and there are as yet no national disaster laws that reference them. In recent years, there has also been concern that the issue of internal displacement is falling off the international agenda. ${ }^{52}$

One of the more concrete indications of the success of the Guiding Principles as a soft law instrument has been the fact that they have directly led to the formulation of the world's first binding regional instrument on internal displacement. The African Union Convention on Protection and Assistance of Internally Displaced Persons in Africa (the Kampala Convention) was adopted by the African Union in 2009 and entered into force in 2012. ${ }^{53}$ Importantly, it is the first binding international treaty to acknowledge climate change as a driver of displacement. Unlike the Guiding Principles, the Convention is a formal, legally binding convention that establishes the obligations of states to prevent displacement, to protect and assist those who have been displaced, and to support solutions to displacement. The Convention spells out the obligation of states to prevent displacement by instituting early warning systems and developing disaster risk reduction strategies. States parties are also required to protect and assist those displaced by disasters, including by climate change.

50. W Kälin, 'Guiding Principles on Internal Displacement' (2008) 38 Stud Transnat'l Legal Pol'y 1.

51. E Ferris, E Mooney and C Stark, From Responsibility to Response: Assessing National Approaches to Internal Displacement (Brookings Institution/London School of Economics Project on Internal Displacement 2011).

52. E Ferris, 'Ten Years After Humanitarian Reform: How Have Internally Displaced Persons Fared?' (12 January 2015) <http://www.brookings.edu/ /media/research/files/papers/2014/12/ 29-idp-humanitarian-reform-reports/introduction-to-final-report-idp-study-final.pdf $>$ accessed 30 May 2016.

53. African Union, 'Convention for the Protection and Assistance of Internally Displaced Persons in Africa (Kampala Convention)' (2009) <http://www.unhcr.org/en-us/4ae9bede9. pdf\#zoom=95> accessed 31 May 2016. 
Finally, states parties are liable to make reparations to IDPs for damages when 'a State Party refrains from protecting and assisting internally displaced persons in the event of natural disasters' (Art 12.3).

In summary, the Guiding Principles on Internal Displacement have provided useful guidance for states and international organizations in the development of policies and programmes to protect and assist IDPs, including those who have to move because of the effects of climate change. More generally, the Principles have also served to raise awareness of the particular needs of IDPs and have been a tool for civil society groups and for IDPs themselves to advocate for better policies. The Guiding Principles have provided a model for the development of soft law initiatives on other issues and have provided the normative grounding for the development of guidelines for operational agencies, including the Operational Guidelines on the Protection of Persons in Situations of Natural Disasters, which are discussed in the following section.

\subsection{Operational Guidelines on the Protection of Persons in Situations of Natural Disasters}

Following the 2004 Indian Ocean tsunami, the Representative of the SecretaryGeneral on the Human Rights of Internally Displaced Persons (RSG) initiated a process to provide guidance to humanitarian organizations working in the aftermath of disasters. ${ }^{54} \mathrm{He}$ called for the development of more general guidance on human rights in humanitarian settings, recognizing that while IDPs have specific needs related to their displacement, others affected by the disaster also often face protection concerns. In 2006, he presented draft guidelines to the Inter-Agency Standing Committee (IASC) on the Protection of Persons in Natural Disasters, which, after field-testing, were revised and adopted by the IASC in $2010 .{ }^{55}$

The Guidelines offer advice on incorporating a human rights approach into both disaster risk reduction and recovery efforts. They emphasize that persons affected by natural disasters should enjoy the same rights and freedoms under human rights law as others in their country and not be discriminated against. The Guidelines also reassert the principle that states have the primary duty and responsibility to provide assistance to persons affected by natural disasters and to protect their human rights, grouped into several clusters of priorities.

Like the Guiding Principles, the Operational Guidelines have served to raise awareness of the importance of a human rights approach in disaster response. Training materials and programmes have been developed to encourage the incorporation of the Operational Guidelines into the policies of international and national humanitarian agencies as well as some governmental agencies. While they initially focused only on disaster response, the Guidelines have also been used to provide human rights guidance for disaster risk reduction and can perhaps be useful in the development of climate change adaptation policies. Building on the relative success of the Operational Guidelines to provide operational guidance for a specific group of people affected by

54. W Kälin, Protection of Internally Displaced Persons in Situations of Natural Disaster: A Working Visit to Asia by the Representative of the United Nations Secretary-General on the Human Rights of Internally Displaced Persons Walter Kälin, 27 February to 5 March 2005 (OHCHR 2005).

55. The Brookings - Bern Project on Internal Displacement, 'Inter-Agency Standing Committee Operational Guidelines on the Protection of Persons in Situations of Natural Disasters' (2011) <http://www.brookings.edu/ /media/research/files/reports/2011/1/06-operational-guidelines-nd/ 0106_operational_guidelines_nd.pdf> accessed 31 May 2016. 
climate change - those affected by sudden-onset disasters - a more recent effort uses a similar approach for another category of those who must move because of the effects of climate change - those who need to be relocated.

\subsection{Guidance on and Operational Guidelines for Planned Relocations}

As noted above, in 2010 the Conference of Parties of the UNFCCC recognized that mobility may be an adaptation strategy for climate change and called for further work on displacement, migration and planned relocations. The Paris Agreement extended this recognition and called for concrete recommendations to be developed. ${ }^{56}$ While there has been considerable work on displacement and migration, much less is known about planned relocations. Although the need for them is likely to increase in the coming years, there has been little guidance or statement of principles to address planned relocations as a protection strategy in response to the adverse effects of climate change. Planned relocations - known as development-induced displacement and resettlement - have been extensively used in the case of development projects and to a lesser extent as a disaster risk reduction strategy, but their applicability in other cases of climate change has received relatively little attention. While there are scattered reports of communities being relocated in response to climate change, the lack of systematic data coupled with the difficulties in attributing causality exclusively to climate change have made it difficult to assess the extent to which such relocations have been - or will be - used as an adaptation strategy for climate change.

Recognizing this gap, from 2011 to 2015, the Brookings Institution, Georgetown University and UNHCR worked on planned relocations. The initiative organized meetings of interested stakeholders in Bellagio, San Remo and again in Bellagio in May 2015. ${ }^{57}$ This most recent meeting brought together experts from different fields and representatives of international organizations and governments to draft the Guidance on Protecting People through Planned Relocations from Disasters and Environmental Change, including Climate Change. ${ }^{58}$ The Guidance is intended to be used by governments and others when planned relocations are necessary to protect people because of disasters and environmental change, including the effects of climate change. A number of background studies and reports shed light on previous experiences with planned relocations and consolidate frameworks and standards from related fields that may be relevant to the issue. ${ }^{59}$

The Guidance is presently being circulated for review by experts working in different fields. Plans are underway for its wide dissemination to governments, practitioners,

56. UNFCCC, 'Decisions adopted by the Conference of the Parties: FCCC/CP/2015/10/ Add.1' (November 2015) para 49 <http://unfccc.int/resource/docs/2015/cop21/eng/10a01. pdf $>$ accessed 28 May 2016.

57. All of these reports and other supporting documents are available at: Brookings-LSE Project on Internal Displacement, 'Planned Relocations, Disasters, and Environmental Change' (2014-2015) <http://www.brookings.edu/about/projects/idp/planned-relocations > accessed 31 May 2016.

58. Brookings, Georgetown, UNHCR, 'Guidance on Protecting People from Disasters and Environmental Change Through Planned Relocation' (7 October 2015) <http://www.unhcr. $\mathrm{org} /$ protection/environment/562f798d9/planned-relocation-guidance-october-2015.html> accessed 2 November 2016.

59. See for example, D Petz, Planned Relocations in the Context of Natural Disasters and Climate Change: A Review of the Literature, Brookings-LSE Project on Internal Displacement, 2015 $<\mathrm{https}$ ://www.brookings.edu/research/planned-relocations-in-the-context-of-natural-disasters-andclimate-change-a-review-of-the-literature/>. 
experts in different fields and affected communities. The hope is that by early 2017 consensus will emerge around the revised Guidance, which can then be incorporated into national laws and policies. At the same time, a companion set of Operational Guidelines will be drafted to synthesize best practices in translating the principles into practice. These Guidelines will address, inter alia, how to develop mechanisms for the participation of people who must be relocated, how to restore livelihoods, and how to secure needed financing to support planned relocations. ${ }^{60}$ Both the Guidance and the Operational Guidelines are intended to serve as a standard by which governments can be held accountable for their actions, to provide concrete support to governments and communities faced with the need to relocate people and to uphold the human rights of those who must be moved because of disasters and the effects of climate change.

This initiative represents an effort to develop soft law to address a gap in the normative framework applicable to those who are forced to move because of the effects of disasters and climate change. Like other soft law initiatives, it builds on existing hard and soft law initiatives - such as binding human rights treaties and the Guiding Principles on Internal Displacement. Experience suggests that it will be important to engage states and operational actors early in the dissemination process in order to garner wide acceptance. A different model of developing soft law - through a state-led process based on regional participatory consultations - was used in the Nansen Initiative discussed below.

\subsection{The Nansen Initiative}

Following the call of the 2010 UNFCCC Cancún Agreement to increase cooperation and coordination regarding climate-change-related mobility, UNHCR convened a Meeting of Experts in early 2011 to examine concrete options for responses to both internal and international climate-related displacement. The subsequent Nansen Conference in June 2011 developed the Nansen Principles to guide the ensuing process, ${ }^{61}$ calling for a sounder knowledge base, describing the responsibilities of a broad range of stakeholders, and highlighting the need for better preventive capacities and more resilience.

The principles also encouraged a more effective implementation of existing frameworks both for internal and international movement. Whereas the Guiding Principles on Internal Displacement were considered an effective yardstick for internal movement, the experts identified an important protection gap associated with cross-border mobility in the context of disasters. ${ }^{62}$ The states present at the Conference, however, resisted addressing cross-border movement. Walter Kälin, later to serve as the Envoy of the Chairmanship of the Nansen Initiative, argued that this was due to 'reasons of sovereignty, competing priorities or the lead role of UNHCR in the process' ${ }^{63}$ To

60. All of these reports and other supporting documents are available at: Georgetown University, Institute for the Study of International Migration, Planned Relocations <https://isim.georgetown. edu/Planned-Relocations $>$ accessed 18 January 2017.

61. W Kälin and N Schrepfer, 'Protecting People Crossing Borders in the Context of Climate Change Normative Gaps and Possible Approaches: http://www.unhcr.org/' [2012] Legal and Protection Policy Research Series <http://www.unhcr.org/4f33f1729.pdf> accessed 25 May 2016.

62. Nansen Initiative, 'Towards a Protection Agenda for People Displaced Across Borders in the Context of Disasters and the Effects of Climate Change' (n.d.) <https://nanseninitiative.org/ secretariat/> accessed 25 May 2016.

63. W Kälin, 'From the Nansen Principles to the Nansen Initiative' [2012] Forced Migration Review 48, 49. 
bypass this lack of willingness, Norway and Switzerland launched a new effort at the UNHCR Ministerial Conference in late 2012.

The Nansen Initiative was a state-owned, yet bottom-up and participatory consultation process. It aimed both to build a better understanding of cross-border displacement resulting from disasters in the context of climate change and to develop a consensus around applicable protection mechanisms. To this end, various regional and sub-regional discussions in disaster hotspot areas brought together representatives of countries of origin and destination, civil society and international organizations over the course of the period 2013-2015. The results from these regional consultations, as well as from additional research, were synthesized at a global intergovernmental consultation in $2015 .{ }^{64}$

The Initiative sought to strengthen protection by detailing conceptual frameworks and good practices that stakeholders could integrate into their existing normative structures to reflect their specific contexts. This quest culminated in the extensive Agenda for the Protection of Cross-Border Displaced Persons in the Context of Disasters and Climate Change, ${ }^{65}$ which establishes standards for both the treatment of affected people and for effective operational responses. Endorsed by 109 government delegations in October 2015, the Agenda addresses questions of admission and stay for cross-border disaster displacement. It also identifies good practices as well as challenges for assistance and protection and examines approaches to durable solutions. Moreover, it considers disaster-risk management in countries of origin and pathways to prevent or mitigate cross-border displacement. Additionally, the Agenda provides a comprehensive toolkit of good practices for all phases of cross-border disaster-displacement. Synthesizing the findings from the consultations, the Agenda also identifies priority areas for future action at national, sub-regional and international levels.

Undoubtedly, the Nansen Initiative has catalysed government attention and action around cross-border mobility in the context of climate change. With more than 100 countries endorsing the Agenda for Protection, and a broad range of actors taking part in the consultations, it has demonstrated how participatory approaches can build interest, buy-in and commitment by stakeholders even on divisive issues. The Nansen Initiative was also successful in building a knowledge base and providing concrete guidance for states to deal with the issue. Moving forward, however, its impact will depend on the effectiveness of the follow-up process. States will need assistance and guidance to adapt the findings into domestic or regional frameworks, and international financing will be required to support them. In this regard, it was encouraging to note the launch of the Platform on Disaster Displacement - as a direct follow-up to the Nansen Initiative under the leadership of the governments of Germany and Bangladesh in May 2016, and the constitution of an Advisory Committee in October 2016. ${ }^{66}$

64. Nansen Initiative, 'Global Consultation: Conference Report' (October 2015) <https:// nanseninitiative.org/wp-content/uploads/2015/02/global-consultation-report.pdf $>$ accessed 25 May 2016.

65. Nansen Initiative (n 7).

66. Platform on Disaster Displacement, 'Germany and Bangladesh commit to address the needs of people displaced across borders in the context of disasters and climate change - Disaster Displacement: Follow-Up to the Nansen Initiative' (24 May 2016) <http://disasterdisplacement. org/germany-and-bangladesh-commit-to-address-the-needs-of-people-displaced-across-bordersin-the-context-of-disasters-and-climate-change/> accessed 31 May 2016. Also see <http://disas terdisplacement.org/advisory-committee-workshop/> accessed 15 October 2016. 


\section{ADDITIONAL PROTECTION POTENTIAL THROUGH HARD LAW}

While we have argued that using soft law represents the most promising approach for those who move because of the effects of climate change, the following sections highlight elements of hard law on human rights, refugees and climate change that offer the potential to complement such efforts.

\subsection{Human rights law}

Generally speaking, international human rights law offers some unique advantages, ${ }^{67}$ including the large number of treaties and signatories, ${ }^{68}$ the extensive scope of the treaties, their far-reaching applicability, their applicability to deal with at-risk populations, and their potential to emphasize the human dimension of climate change ${ }^{69}$ International human rights law also forms the bedrock of international migration governance. ${ }^{70}$ Despite an increasing acknowledgement of the relevance of human rights in the context of climate change, however, ' $[\mathrm{t}$ ] $\mathrm{he}$ track record of most countries in treating victims of displacement as rights-holders ... is very poor' ${ }^{71}$ In fact, the growth in norms, monitoring bodies and ratifying states does not seem to have been accompanied by a significant decrease in human rights violations in most cases. ${ }^{72}$

Much further work - particularly in areas of implementation, accountability and compliance - is needed for the human rights system in its present form to prevent and respond to the human rights violations of those displaced in the context of climate change. While international human rights law sets the frame of rights applicable to all kinds of mobility in the context of climate change, the challenge remains in translating the wide array of human rights responsibilities already assumed by states into practice.

\subsection{International refugee law}

As noted above, refugee law in its current form will only cover a very small group of people affected by climate change, those that suffer from ensuing conflict, persecution,

67. For a detailed discussion of the rationale for rights-based approaches to climate change, see Caney (n 16); S Humphreys, Human Rights and Climate Change (Cambridge University Press, Cambridge 2010).

68. Including the International Bill of Human Rights (Universal Declaration of Human Rights 1948; International Covenant on Civil and Political Rights 1966; International Covenant on Economic, Social, and Cultural Rights 1966; and their protocols); International Convention on the Elimination of All Forms of Racial Discrimination 1965; Convention on the Elimination of All Forms of Discrimination against Women 1979 and Protocol 1999; Convention against Torture 1984 and Protocol 2002; Convention on the Rights of the Child 1989 and Protocols of 2000 and 2011; International Convention on the Protection of the Rights of All Migrant Workers and Members of Their Families 1990; Convention on the Rights of Persons with Disabilities 2006 and Protocol 2006, and others.

69. ICHRP, 'Climate Change and Human Rights' (2008), iii <http://www.ichrp.org/files/ reports/45/136_report.pdf> accessed 23 April 2015.

70. See, for example, the analysis, research and database on international migration law of the International Organization for Migration: IOM, 'International Migration Law' (n.d.) <http:// www.iom.int/international-migration-law> accessed 24 June 2016.

71. S Lecki, 'Human Rights Implications' [2008] Forced Migration Review 18, 18.

72. OA Hathaway, 'Do Human Rights Treaties Make a Difference?' [2002] Yale Law Journal 1935; OA Hathaway, 'The Cost of Commitment' [2003] Stanford Law Review 1821. 
or a breakdown of public order. Even here, however, the Convention only protects those who move across borders, leaving the largest forms of climate mobility - internal movement, and potentially entrapment - uncovered. States are suspicious of extending legal obligations to other categories of displaced persons. Negotiating a new protocol or amendment to the Refugee Convention is thus unlikely, and were such negotiations to occur, they could prove counterproductive.

Some regional instruments such as the 1969 OAU Convention on the Specific Aspects of Refugee Problems in Africa and the 1984 Cartagena Declaration on Refugees have moved beyond the narrow definition of the Geneva Convention. They acknowledge that international protection may be needed for events that seriously disturb public order and thus potentially provide protection for people displaced by circumstances accompanying disasters. ${ }^{73}$ More recently, the Brazil Plan of Action, adopted in December 2014 by 28 countries, explicitly mentions climate change as a challenge to the region and calls on UNHCR to support the development of national and regional policies to respond to those forced to move because of climate change and disasters. ${ }^{74}$ There may be potential benefits in applying these regional instruments and encouraging the development of similar instruments in other regions.

A similar argument can be made for complementary protection. Complementary protection, that is, regional and national norms for temporary or subsidiary protection, has arisen to fill some protection needs outside the Geneva Convention. ${ }^{75}$ An EU directive, for instance, allows the establishment of temporary protection for people facing generalized violations of human rights in their home countries, although it has never been applied. ${ }^{76}$ Subsidiary protection can be claimed in the EU when applicants face the risk of serious harm such as indiscriminate violence in their home countries. ${ }^{77}$ While neither of these measures explicitly references climate-related risks, more frequent and intense disasters may increase the likelihood of generalized

73. Regional instruments such as the 1969 OAU Convention and the 1984 Cartagena Declaration apply a wider definition of refugees that includes events which seriously disturb public order, thus potentially encompassing disasters. This was used by some states in the Horn of Africa during the 2011-12 droughts to admit people displaced from Somalia, and by others in Latin America to grant asylum to Haitians displaced by the 2010 earthquake. Other Latin American states even found that Haitian asylum seekers had a 'well-founded fear of persecution by non-state actors that arose from the vacuum of governmental authority after the earthquake' (Nansen Initiative (n 7) 54).

74. 'Brazil Declaration: A Framework for Cooperation and Regional Solidarity to Strengthen the International Protection of Refugees, Displaced and Stateless Persons in Latin America and the Caribbean' (Brasilia 3 December 2014) <http://www.acnur.org/t3/fileadmin/scripts/doc. php?file=t3/fileadmin/Documentos/BDL/2014/9865 $>$ accessed 24 June 2016.

75. A Williams, 'Turning the Tide: Recognizing Climate Change Refugees in International Law' (2008) 30(4) Law \& Policy 502.

76. EU, 'Directive 2001/55/EC of 20 July 2001 on minimum standards for giving temporary protection in the event of a mass influx of displaced persons and on measures promoting a balance of efforts between Member States in receiving such persons and bearing the consequences thereof' <http://eur-lex.europa.eu/LexUriServ/LexUriServ.do?uri=OJ:L:2001:212:0012:0023: EN:PDF> accessed 6 June 2016.

77. EU, 'Directive 2011/95/EU of the European Parliament and of the Council of 13 December 2011 on standards for the qualification of third-country nationals or stateless persons as beneficiaries of international protection, for a uniform status for refugees or for persons eligible for subsidiary protection, and for the content of the protection granted' < http://eur-lex.europa.eu/ legal-content/EN/TXT/PDF/?uri=CELEX:32011L0095\&from=EN> accessed 6 June 2016. 
human rights violations and indiscriminate violence and thus make the regimes applicable.

Nonetheless, as McAdam argues, the concept of complementary protection would 'need to be substantially developed' before it could become more generally applicable to climate-change-related displacement. ${ }^{78}$ Even if granted, the norms do not offer permanent solutions but rather serve as ad hoc and provisional gap-fillers. Moreover, as the norms often reflect the lowest common denominator, they tend to establish weak protection standards. ${ }^{79}$ In sum, some authors hold that complementary protection may at least catalyse 'initial international support for managing climate change-related displacement' and create a 'foothold ... to shore up a subsequent, more permanent status', ${ }^{80}$ while others argue that such regimes offer 'little additional value'. ${ }^{81}$ Although far from perfect, further developing subsidiary and temporary protection schemes could at least bridge some of the protection gaps witnessed in the context of climate-change-related displacement. The next section discusses how features of another hard law regime, namely climate change law, may contribute to protection.

\subsection{The international climate change regime}

The UN Framework Convention on Climate Change (UNFCCC) is the major legal framework for international climate action. Only concerted advocacy before the sixteenth Conference of the Parties (COP) brought human mobility more significantly into the UNFCCC negotiations. ${ }^{82}$ Thanks to these efforts, states adopted the Cancún Adaptation Framework in late 2010, which recognized human mobility as part of the adaptation challenges to climate change. ${ }^{83}$ An Advisory Group on Climate Change and Human Mobility providing technical assistance to the Parties and advocacy was established. ${ }^{84}$ Cancún thereby created important momentum and legitimacy for the issue and could potentially open access to international climate financing for mobility-related adaptation measures. ${ }^{85}$

After Cancún, migration, displacement and relocation figured more visibly in the negotiations. ${ }^{86}$ The Warsaw International Mechanism for Loss and Damage (WIM)

78. J McAdam, 'Climate Change Displacement and International Law: Complementary Protection Standards: PPLA/2011/03' (May 2011) Legal and Protection Policy Research Series <http://www. unhcr.org/4dff16e99.pdf\#zoom=95> accessed 31 May 2016.

79. Ibid.

80. Ibid 49.

81. Williams (n 75) 514.

82. K Warner, 'Climate Change Induced Displacement: Adaptation Policy in the Context of the UNFCCC Climate Negotiations: PPLA/2011/02' (2011) $1<$ http://www.unhcr.org/ 4df9cc309.pdf> accessed 26 May 2016.

83. It called on parties to improve adaptation efforts by, amongst other things, taking 'measures to enhance understanding, coordination and cooperation with regard to climate change induced displacement, migration and planned relocation, where appropriate, at national, regional and international levels', cf UNFCCC, 'Cancun Agreements: Cancun Adaptation Framework, Paragraphs 11-35, Decision 1.CP/16' Paragraph 14(f) <http://unfccc.int/resource/docs/ 2010/cop16/eng/07a01.pdf\#page=4> accessed 26 May 2016.

84. Advisory Group on Climate Change and Human Mobility, 'Human Mobility in the Context of Climate Change UNFCCC Paris COP-21: Recommendations' (November 2015) <http:// www.unhcr.org/protection/environment/565b21 bd9/human-mobility-context-climate-changeunfccc-paris-cop-21-recommendations.html> accessed 28 May 2016.

85. Warner (n 82).

86. In 2012, for instance, the COP 18 in Doha called on parties to improve the understanding of how climate change is affecting 'patterns of migration, displacement and human mobility', cf 
associated with climate change was established in COP 19 and seeks, inter alia, to improve the knowledge base on the relationship between climate change and migration, enhance cooperation amongst states, and provide technical support on approaches to address loss and damage. The Advisory Group on Climate Change and Human Mobility established in Cancún continues its support to the associated WIM Executive Committee, ${ }^{87}$ and there is growing recognition by states that human mobility constitutes an adaptation as well as a loss and damage issue.

The COP 21 in 2015 led to the Paris Agreement, in which virtually all states agreed for the first time on partially binding ${ }^{88}$ intended nationally determined contributions (INDCs) to limit climate change and its adverse impacts. About 20 per cent of the submitted INDCs mention human mobility, mostly those authored by countries expected to be most affected by climate change. These references revolve around security implications, migration as adaptation, and remittances as a contribution to climate action. ${ }^{89}$ In its preamble, the Paris Agreement notes the rights of migrants when taking climate action, and the COP Decision establishes a task force under the Warsaw Mechanism to 'develop recommendations for integrated approaches to avert, minimise and address displacement related to the adverse impacts of climate change'. ${ }^{90}$

While the Mechanism currently reviews expert submissions on the topic ${ }^{91}$ and could soon issue its first recommendations on relief and facilitation of mobility, ${ }^{92}$ it still lacks coherent funding and the associated questions of liability and compensation remain highly contentious. ${ }^{93}$ Furthermore, Paris did not address questions of legal status, protection and assistance for people moving in the context of climate change.

UNFCCC, 'Report of the Conference of the Parties on its eighteenth session, held in Doha from 26 November to 8 December 2012: 3/CP.18. Approaches to address loss and damage associated with climate change impacts in developing countries that are particularly vulnerable to the adverse effects of climate change to enhance adaptive capacity' (2012) <http://unfccc.int/ resource/docs/2012/cop18/eng/08a01.pdf> accessed 28 May 2016.

87. IOM, 'COP21 Paris Agreement: A Stepping Stone for Climate Migrants' (December 2015) <http://weblog.iom.int/cop21-paris-agreement-stepping-stone-climate-migrants> accessed 28 May 2016.

88. Due to political constraints in the USA and other countries, not all of the agreement is considered legally binding, though the legal discussion continues, cf A Savaresi, 'The Paris Agreement: A New Beginning?' (2016) 34(1) Journal of Energy \& Natural Resources Law 16. The agreement opened for signature for one year in April 2016 and will enter into force after 55 countries accounting for at least 55 per cent of global emissions have ratified it. As of May 2016, there were 177 signatories, and 17 ratifications of the Agreement.

89. IOM, 'Ahead of COP21 Intended Nationally Determined Contributions Take Stock of Human Mobility Questions I Newsdesk' <https://weblog.iom.int/ahead-cop21-intended-nationally-deter mined-contributions-take-stock-human-mobility-questions> accessed 28 May 2016.

90. UNFCCC, 'Decisions adopted by the Conference of the Parties: FCCC/CP/2015/10/ Add.1' (November 2015) para $50<$ http://unfccc.int/resource/docs/2015/cop21/eng/10a01. pdf> accessed 28 May 2016.

91. UNFCCC, 'Executive Committee of the Warsaw International Mechanism for Loss and Damage: Submissions on Migration' (16 May 2016) <http://unfccc.int/adaptation/groups_ committees/loss_and_damage_executive_committee/items/9508.php> accessed 29 May 2016.

92. WCG Burns, 'Loss and Damage and the 21st Conference of the Parties to the United Nations Framework Convention on Climate Change' [2 January 2016] available at SSRN: $<$ https://ssrn.com/abstract=2710086> or $<$ http://dx.doi.org/10.2139/ssrn.2710086>.

93. M Burkett, 'Reading Between the Red Lines: Loss and Damage and the Paris Outcome' (2016) 6(1-2) Climate Law 118. 
Thus, while some have called the inclusion of migration in the preamble of the Paris Agreement an 'unprecedented breakthrough', ${ }^{44}$ it is far from a being a comprehensive approach. Facing the slow progress on the issue, some authors have argued that the UNFCC is not an adequate place to deal with displacement, holding that the Framework lacks the necessary institutions and capacities and already faces difficulties in achieving progress on less contentious core functions. ${ }^{95}$

Others make the opposite case, arguing in favour of the potential of the UNFCCC to 'prevent and reduce climate change-related displacement'. ${ }^{96}$ This view may hold true for three reasons. First, the establishment of the WIM can offer new impetus to the issue and potentially lead to a discussion on vital funding questions. Second, the National Adaptation Plans (NAPs, following the former National Adaptation Programmes of Action (NAPAs)) established under the Cancún Framework offer an opportunity to integrate human mobility more thoroughly into climate action. So far, however, the strategies on mobility embedded in these plans still lack the level of sophistication required to address climate-change-related mobility adequately. ${ }^{97}$ Once the knowledge base on the relationship between adaptation and mobility improves, NAPs could become an important tool to advance protection. Third, the Paris negotiations considered for the first time a 'Climate Change Displacement Facility' under the UNFCCC to provide emergency relief as well as to assist in providing organized migration, planned relocation, and to undertake compensation measures. ${ }^{98}$ However, the relevant clauses in a draft version were met with resistance by a few states, particularly Australia, and were not included in the Paris Agreement. With major stakeholders such as the USA, UK and France open to the idea, however, the resistance by a few could wane in the foreseeable future. The Facility could thereby become an important avenue for a more potent approach to mobility questions. ${ }^{99}$ Certainly, embedding human mobility into the binding Paris Agreement by using non-normative framing brought attention to the issue in one of the most influential policy fora. ${ }^{100}$

\subsection{ILC Draft Articles on the Protection of Persons in the Event of Disasters}

While the UNFCCC and other treaty regimes have not yet fully addressed climatechange-related displacement, an effort is underway to better take up one particular aspect

94. IOM (n 87).

95. David Hodgkinson and Lucy Young, 'In the face of looming catastrophe: a convention for climate change displaced persons (updated version)' (2012) <http://www.ccdpconvention.com/ documents/Updated\%20treaty\%20proposal.pdf> accessed 26 May 2016.

96. Advisory Group on Climate Change and Human Mobility (n 84) 3.

97. K Warner et al., 'National Adaptation Plans and Human Mobility' [2015] Forced Migration Review 8.

98. Cf paragraphs 70.3(a) and 76 of the Paris Draft Agreement; Advisory Group on Climate Change and Human Mobility, 'Human Mobility in the Context of Climate Change: Elements for the UNFCCC Paris Agreement' (March 2015) <http://www.unhcr.org/5550ab359.pdf> accessed 7 June 2016; Phillip Warren, 'Evaluating the "Climate Change Displacement Coordination Facility": How the UNFCCC Can Address Forced Migration after Paris Cop21' [2016] Columbia Law Review, forthcoming.

99. O Milman, 'UN Drops Plan to Help Move Climate-change Affected People' The Guardian (6 October 2015) <http://www.theguardian.com/environment/2015/oct/07/un-drops-planto-create-group-to-relocate-climate-change-affected-people> accessed 29 May 2016.

100. Warner (n 82) 13. 
of the issue. The International Law Commission (ILC), a UN body called upon by states to further the development of international law, has sought to establish hard law to protect people displaced by disasters. After the failure of several efforts in the 1980s to develop a binding legal framework regulating humanitarian assistance for disasters outside armed conflicts, the 1990s brought new attention to the topic, ${ }^{101}$ leading to the elaboration of 'Draft Articles on the Protection of Persons in the Event of Disasters'. ${ }^{102}$ After adopting a first full draft in 2014 and considering comments by stakeholders at meetings in May 2016, the Drafting Committee is now finalizing its work. ${ }^{103}$

The present 21 Draft Articles aim to frame an effective response to disasters, detailing both the rights and obligations of affected states and other international actors. The Draft Articles also spell out humanitarian and human rights standards for assistance. The Draft Articles define a 'disaster' as 'a calamitous event or series of events resulting in widespread loss of life, great human suffering and distress, displacement, or large-scale material, economic or environmental damage, thereby seriously disrupting the functioning of society' (Art 3, emphasis added). With this broad definition covering both human-made and environmental disasters, the Articles would be of relevance for displacement in the context of climate change.

That said, it is not entirely clear whether the Draft Articles would also apply to slow-onset disasters. Moreover, while displacement is explicitly referred to in the definition, the International Organization for Migration (IOM) and others have argued that neither the full range of human mobility - including anticipatory migration as adaptation - nor the specific vulnerabilities of migrants are adequately reflected in the current draft. ${ }^{104}$ While the 'needs of the most vulnerable' are referenced in Art 7, the IOM advocates for further clarification of these issues in the commentary to the Articles, with particular attention to displacement indirectly caused by disasters as well as to host communities, an often omitted variable in the discussion. ${ }^{105}$

In addition, the perennial discussion about the extent of state sovereignty and a potential duty to assist and to accept assistance after disasters will continue. ${ }^{106}$ According to the Draft Articles, the affected state remains the ultimate gatekeeper, although it shall not 'withhold or withdraw arbitrarily' consent to external assistance (Art 14 II). The considerable amount of time and resources devoted to these

101. D Cubie, 'An Enchanted Tool? Humanitarian Assistance and the ILC Draft Articles on the Protection of Persons in the Event of Disasters' (2010) IV-V Irish Yearbook of International Law 119.

102. Available here: ILC, 'Reports of the Special Rapporteur on the protection of persons in the event of disasters' (2008-2016) <http://legal.un.org/ilc/guide/6_3.shtml\#srapprep> accessed 29 May 2016.

103. UNGA, 'ILC - Protection of persons in the event of disasters: Comments and observations received from Governments and international organizations' (A/CN.4/696 and Add. 1 2016) <https://documents-dds-ny.un.org/doc/UNDOC/GEN/N16/070/30/PDF/N1607030.pdf? OpenElement and http://legal.un.org/docs/?symbol=A/CN.4/696/Add.1> accessed 28 May 2016; UNGA, 'ILC - Eighth report on the protection of persons in the event of disasters: A/ CN.4/697' (Eduardo Valencia, Special Rapporteur 2016) <https://documents-dds-ny.un.org/ doc/UNDOC/GEN/N16/074/30/PDF/N1607430.pdf?OpenElement> accessed 28 May 2016.

104. UNGA, 'ILC - Protection of persons in the event of disasters' (ibid).

105. UNGA (n 103).

106. S Davies, 'Natural Disasters and the Responsibility to Protect' (2012) 55 German Yearbook of International Law 149; H-J Heintze, 'The ILC Codification Project on the "Protection of Persons in the Event of Disasters"' in P Gibbons and H-J Heintze (eds), The Humanitarian Challenge (Springer 2015). 
negotiations reflect the general caution of states concerning the assumption of new obligations for climate-change-related displacement that may infringe on their sovereignty.

In a similar vein, while the codification process is coming to a close, discussion on the final format of the Draft Articles has continued. Implementation as a binding framework convention, as proposed by the ILC and its Special Rapporteur, was supported by the UN General Assembly Sixth Committee, the International Federation of the Red Cross (IFRC), the World Food Programme and others, arguing that only a binding instrument could create new momentum. Several major states, however, deemed the existing legal framework to be sufficient and saw more practical value in non-binding guidelines or in a framework of principles and recommendations. ${ }^{107}$ It thus remains to be seen in which format the Draft Articles will be finalized, and how their effect will unfold.

\section{CONCLUSIONS: MOVING AHEAD WITH SOFT LAW, COMPLEMENTED BY HARD LAW}

We have argued that the potential of hard law to protect those displaced by the effects of climate change appears at best limited. First, while international human rights law sets the frame of rights applicable to all kinds of mobility in the context of climate change, it fails to offer specific guidance and effective remedies. Second, international refugee law in its current form will likely apply to a very small group of people displaced by the effects of climate change, ${ }^{108}$ and amendments are improbable. Third, international climate law has given the discussion on human mobility some momentum but certainly does not bridge imminent protection gaps. Fourth, the ILC Draft Articles on the Protection of Persons in the Event of Disasters have no specific focus on the vulnerabilities and resiliencies of affected populations, nor do they cover either the full range of human mobility or climate change impacts. The probability of adopting them as a binding convention also seems low given the current political climate.

While opportunities to introduce climate-change-related mobility into future treaties need to be harnessed to the fullest extent possible, especially in the context of the UNFCCC, this will be a long-term and challenging process even in the best-case scenario. Building on existing hard law, two alternative ways forward are, first, to focus on improving norms of complementary protection and, second, to regionalize protection approaches. Complementary protection norms may prove more flexible than the Geneva Convention for the incorporation of changing protection needs in the context of climate change. ${ }^{109}$ Far from perfect, further development of such subsidiary and temporary protection schemes could at least bridge some of the protection gaps

107. Cubie (n 101).

108. Namely those moving internationally who flee from ensuing conflict, persecution, or breakdown of public order.

109. The case of a Kiribati citizen who appealed as the 'first climate refugee' in New Zealand exemplifies this. While his claim was dismissed as not covered under the Refugee Convention, his family eventually received subsidiary protection on exceptional humanitarian grounds, mostly due to his children's integration prospects; cf A Maas, 'Tuvalu Climate Change Family Win NZ Residency Appeal' The New Zealand Herald (3 August 2014) <http://www.nzherald. co.nz/nz/news/article.cfm?c_id=1\&objectid=11303331>. 
witnessed in the context of climate change mobility and catalyse further action. On the other hand, more regional solutions that provide tailored approaches to climatechange-related displacement could help to overcome negotiation logjams and coordination obstacles. Such processes could foster building blocks that catalyse a more comprehensive solution in the long run. A range of regional processes and consultative mechanisms could be built upon. The 2009 Kampala Convention on internal displacement, for instance, has shown that climate change can be an explicit focus of binding, regional protection instruments. ${ }^{110}$ As the first binding regional treaty to make such a connection, the Kampala Convention could serve as a model for other regional efforts. Further regional agreements apply to those who move across borders, such as the ECOWAS Protocol on Free Movement of Persons (1979) and its Common Regional Approach on Migration (2008). ${ }^{111}$ These instruments seem like a particularly promising way forward as they provide for free movement of people within the sub-region without needing to determine the causes of such movement, thus bypassing the sticky issue of disentangling the role of climate change. Furthermore, other regional refugee instruments such as the 1969 OAU Convention, the 1984 Cartagena Declaration, and the 2014 Brazil Declaration, each offer the possibility of opening the door to those displaced by disasters. In a few cases, they have already been used to this end. ${ }^{112}$ The potential may exist to harness them for the future protection of cross-border, climate-related displacement and to develop similar initiatives in other regions.

The analysis above has also shown that existing and emergent soft law ${ }^{113}$ offers potential to bridge some of the gaps identified in existing hard law regimes. First, the Guiding Principles on Internal Displacement have been successfully translated into national laws and policies by more than twenty governments as well as into one binding regional agreement with explicit reference to climate change. The influence of the Guiding Principles on national disaster laws, a central aspect of climaterelated displacement, needs to be increased. Second, the Operational Guidelines on the Protection of Persons in Situations of Natural Disasters have served to raise awareness of the importance of a human rights approach in disaster response. The Guidelines have also been used to provide human rights guidance for disaster risk reduction and can perhaps be useful in the development of climate change adaptation policies. Third, the Guidance on and Operational Guidelines for Planned Relocations provide support to and uphold the human rights of those who must be moved because of disasters and the effects of climate change. If processed effectively, these could be developed into a standard by which governments can be held accountable for their actions. Lastly, the Nansen Initiative has catalysed government attention and action around cross-border mobility in the context of climate change. The Initiative has built interest,

110. African Union (n 53).

111. ECOWAS, 'Protocol A/P.1/5/79 Relating to Free Movement of Persons, Residence and Establishment' (29 May 1979) <http://documentation.ecowas.int/download/en/legal_documents/ protocols/PROTOCOL\%20RELATING\%20TO\%20\%20FREE\%20MOVEMENT\%20OF\% 20PERSONS.pdf> accessed 30 May 2016; ECOWAS Commission, 'Common Approach on Migration' (18 January 2008) <http://www.unhcr.org/49e47c8f11.pdf> accessed 5 June 2016. 112. Nansen Initiative (n 7).

113. As discussed above, the ILC Draft Articles on the Protection of Persons in the Event of Disasters are not yet adopted in a binding form, but may be considered as emerging soft law. They are not examined again here. 
buy-in and commitment by stakeholders even on this divisive issue and created a knowledge base that provides concrete guidance for states to deal with the issue.

Overall, soft law has proved more dynamic than most hard law regimes. Various soft law initiatives on the environment-migration nexus have been conducive to addressing the needs of affected populations falling through current protection cracks. Soft law has also provided new tools for human rights and other civil society groups to hold governments accountable. That said, a downside of all these ad-hoc initiatives is that they may also bring about fragmentation of protection systems, resources and attention. They have all developed their own processes, constituencies and terminology, which will be difficult to consolidate into a comprehensive international treaty if changes in the political context should at some point open a window of opportunity.

Furthermore, it is clear that norms - whether binding treaties or soft law instruments - must be translated into policy and practice in order to make a difference in the lives of people affected by climate change. For norms to become effective and to lead to compliance, they need to induce a combination of coercion and persuasion, as Hafner-Burton argues in the case of human rights law. ${ }^{114}$ Of course, the real impact of both hard and soft law remains a function of rigorous follow-up processes, including targeted advocacy, as well as technical, financial and implementation support to enable the recommended extent and quality of actions. For soft law in particular to become effective, the importance of both regional agreements and strategic implementation leadership has been emphasized before. ${ }^{115}$

Another potential approach is to focus on the operational level, by formulating guidance that can be translated into national laws and policies without the development of new normative global frameworks. On this practical level, there have been valuable efforts to incorporate a rights-based approach to natural disaster response. For example, the Operational Guidelines on the Protection of Persons in Situations of Natural Disasters offer governments a very practical way of dealing with immediate needs. Similarly, the effort of the International Federation of the Red Cross to develop International Disaster Response Law is an important step to strengthen national capacity to respond to disasters. ${ }^{116}$

A more operational approach may also work through climate change adaptation efforts. Since migration has been recognized as a form of adaptation, ${ }^{117}$ climate change adaptation processes could help to develop practical policies on regional, national and sub-national levels that address protection needs for people threatened by climatechange-related displacement. Such processes could, in the long run, also help to develop better laws. With the latest COP at least partially approaching the issue, there could be some potential for making progress under the UNFCCC, especially through NAPs, the Warsaw Mechanism processes, and a renewed discussion about a Climate Change Displacement Facility.

Finally, to address climate change mobility in a more comprehensive fashion - rather than the present piecemeal process - yet another approach would be to advocate for a new soft law process. ${ }^{118}$ The Global Forum on Migration and Development or a new Global Commission could consider the needs and compile existing good practices for mobility

114. Hafner-Burton (n 24).

115. Shelton (n 42).

116. IFRC, 'IDRL Disaster Law - Background on the Programme' (n.d.) <http://www.ifrc.org/ en/what-we-do/disaster-law/about-idrl/background-on-the-programme/> accessed 7 June 2016. 117. UNFCCC (n 83); UNFCCC (n 86).

118. Betts (n 26). 
associated with climate change. A new General Assembly resolution could advance the development of normative frameworks applicable to those who move in the context of climate change. ${ }^{119}$ Yet another way forward would be to include climate change mobility in current UN efforts to develop guidance on 'vulnerable' or 'crisis migrants'. ${ }^{120}$

\section{LOOKING FORWARD: WHERE TO NEXT?}

It seems clear that the development of normative frameworks to protect those displaced because of the effects of climate change will have to use both available soft and hard law avenues to the best extent possible. Yet given the significant challenges of collective action on the issue, protection gaps will probably persist. It is also evident that norms by themselves will not be enough. National and international civil society efforts will be vital to create a bottom-up demand for change, to hold governments accountable, to provide innovative solutions and expertise on the issue, to further the translation of norms, initiatives and values into binding national law, and to contribute to new shared understanding and legitimacy for protection issues. Beyond all normative efforts, the international community must also take practical action to radically take the edge off climate change, preventing the most adverse effects as long as it is still possible. The cost of inaction will certainly be higher than stringent climate mitigation measures. As the Nansen Initiative argues, '[p]eople forced to move is a powerful reminder that urgent action is needed to reduce climate change'. ${ }^{121}$

119. Mayer, 'International Legal Challenges of Climate-Induced Migration: Proposal for an International Legal Framework' (n 30).

120. UNGA, 'In Safety and Dignity: Addressing Large Movements of Refugees and Migrants: Report of the Secretary-General A/70/59' (9 May 2016) <http://refugeesmigrants.un.org/sites/ default/files/in_safety_and_dignity_-_addressing_large_movements_of_refugees_and_migrants. pdf $>$ accessed 30 May 2016.

121. Nansen Initiative, 'The Nansen Conference - Climate Change and Displacement in the 21st Century' (Oslo, Norway 5 June 2011), 4 <http://www.unhcr.org/4ea969729.pdf> accessed 6 June 2016. 